Research Paper

\title{
The Effectiveness of Compassion-based Therapy on Post Traumatic Growth in Mothers of Children with Attention Deficit/Hyperactivity Disorder
}

\author{
Mojgan Navab ${ }^{1}$, Akram Dehghani ${ }^{* 2}$, Afsaneh Karbasi ${ }^{3}$ \\ 1. M.A. in Clinical Psychology, Faculty of Psychology, Najafabad Branch, Islamic Azad University, Najafabad, Iran \\ 2. Assistant Professor, Department of Clinical Psychology, Faculty of Psychology, Najafabad Branch, Islamic Azad University, \\ Najafabad, Iran \\ 3. Assistant Professor, Department of Psychiatry, Faculty of Medical Science, Isfahan University of Medical Science, Iran
}

Accepted: October 21, 2018

\begin{abstract}
Background and Purpose: Children with attention deficit / hyperactivity disorder (ADHD) suffer from developmental and functional defects that can cause serious damages to the family, including mother-child relationships. This study sought to determine the effectiveness of compassion-based therapy on post-traumatic growth in mothers of children with ADHD.

Method: This study was a semi-experimental study with pretest-posttest control group design. The sample of this study included 20 mothers with children with ADHD in Isfahan city in 2017 who were selected by purposeful sampling and were randomly assigned to the experimental and control groups. Data were collected using the Tedeschi and Calhoun scale (1996). Participants in the experimental group received a compassion-based therapy in 8 sessions of 90 minutes, whereas the control group received no intervention. For analyzing the data, covariance analysis was used.

Results: The results showed that the method of compassion-based therapy improved the sense of internal power and change in goals and priorities of life, while it had no effect on the feeling of proximity and intimacy with others and trying to maintain relationships with others. $(p<0.05)$. Conclusion: According to the findings of this study, it can be concluded that compassionfocused therapy can be used to manage, organize and prioritize activities in mothers of children with ADHD.

Keywords: Compassion focused therapy group, post traumatic growth, attention deficit/ hyperactivity disorder
\end{abstract}

Citation: Navab M, Dehghani A, Karbasi A. The effectiveness of compassion-based therapy on post traumatic growth in mothers of children with attention deficit/hyperactivity disorder. Quarterly Journal of Child Mental Health. 2019; 6(1): 239-250.

*Corresponding author: Âkram Dehghani, Assistant Professor, Department of Clinical Psychology, Faculty of Psychology, Najafabad Branch, Islamic Azad University, Najafabad, Iran. 


\title{
اثربخشى كروهدرمانى مبتنى بر شفقت بر رشد يِ از سانحه در مادران كودكان با اختلال

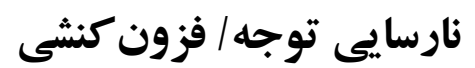

\author{
مز كان نواب'، اكرم دهقانى "r، افسانه كرباسى

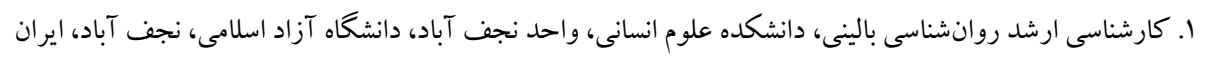

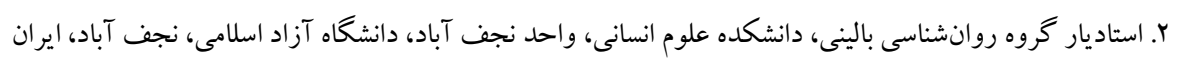

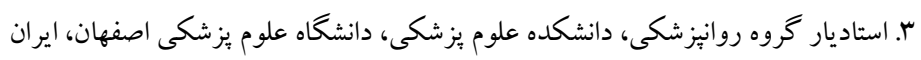

تاريخ بذيرش:

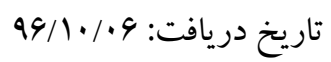

جكکن

زمينه و هدف: كود كى با اختلال نارسايى توجه/ فزون كنشى داراى نارسايىهاى كنشى و تحولى است كه مى تواند آسيبهاى جدى

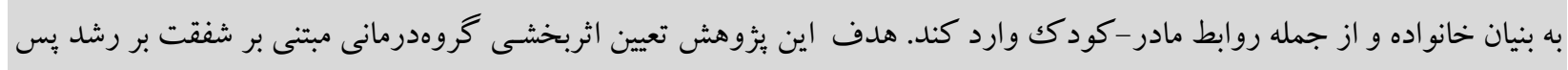

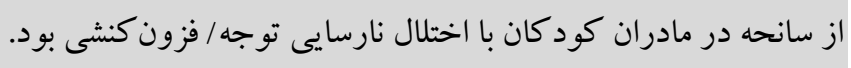

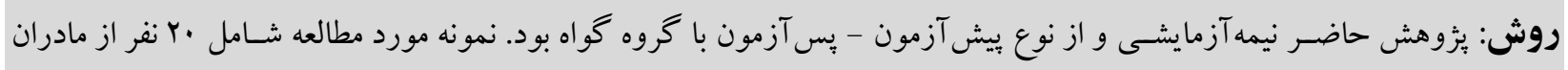

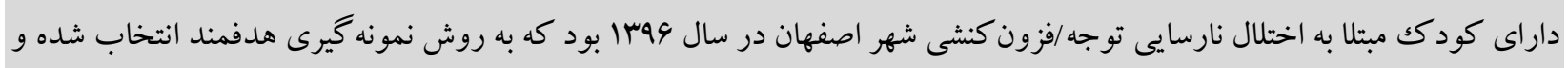

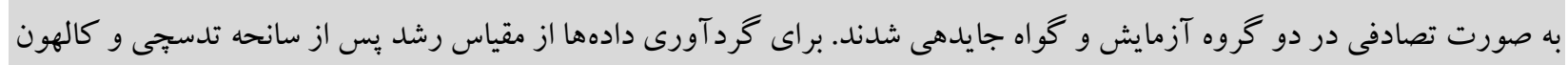

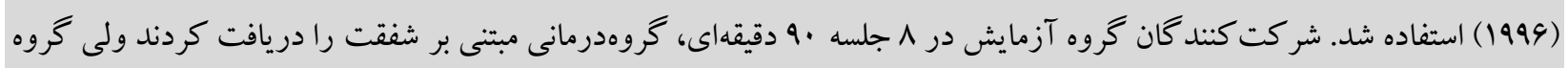
كواه مداخلهاى رادريافت نكردند. براى تجزيه و تحليل دادهها از آزمون تحليل كواريانس استفاده شده.

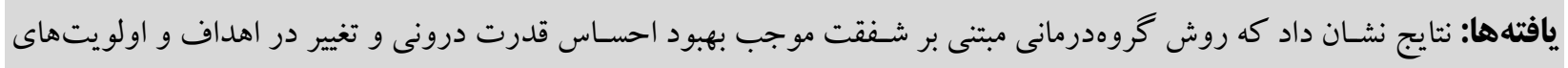

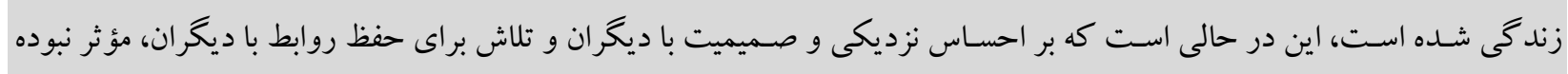

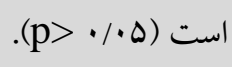

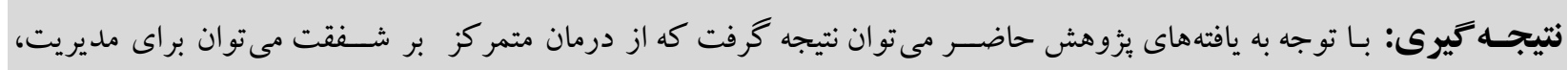

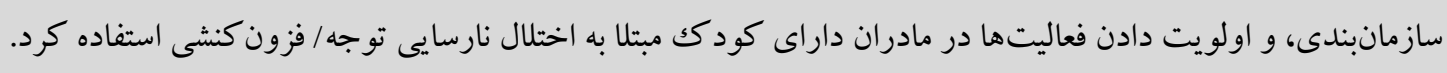

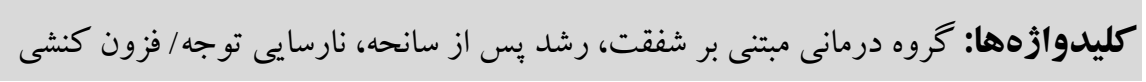

*نويسنده مسئول: اكرم دهقانى، استاديار گروه روانشناسى بالينى، دانشكده علوم انسانى، واحد نجف آباد، دانشكاه آزاد اسلامى، نجف آباد، ايران. تلفن: ايميل:phoh.iaun.ac.ir 
همه مهمتر نقش محيط خانواده يعنى جگگونخى برخورد و

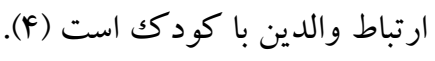

بسيارى از بزووهش هايى كه به بررسى تأثير رفتار والدين بر برد

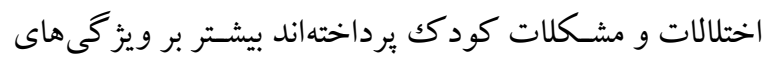

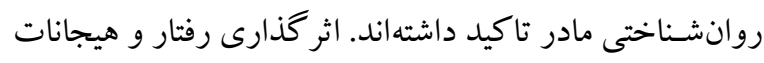
والدين بر مؤلفههاى سـلامت رفتارى و روانشــاختى كود كان تنها يكك بعد ماجر ا است و بعد دوم اثر كذارى رفتارها و نقايص تول

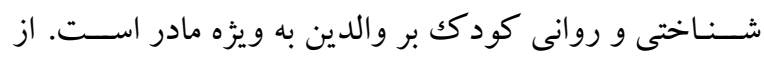

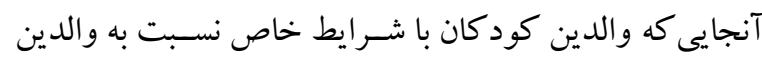

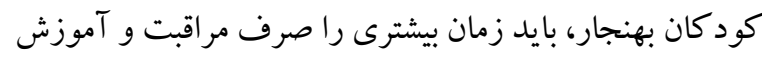
كود كشان كنند در نتيجه براى انجام فعاليتهاى خود ناتواناند

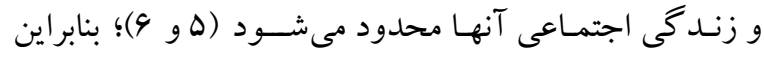

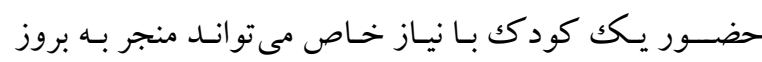

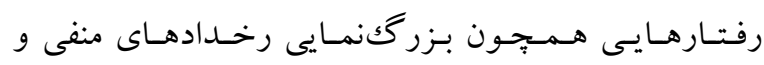

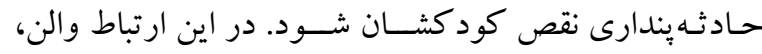

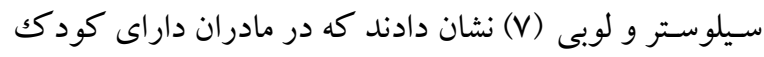

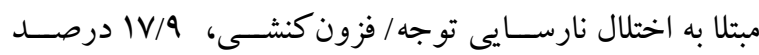

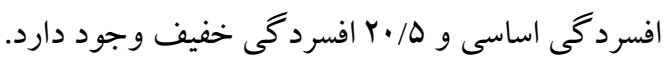

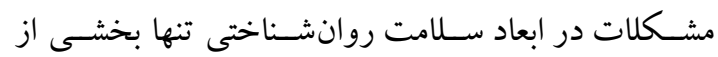
واكنش مادران به مشـككلات رفتارى كود كانشــان را توجيه مى كند و رشد بِ از سانحه بنيز به عنوان دركى مثبتى از ابعاد

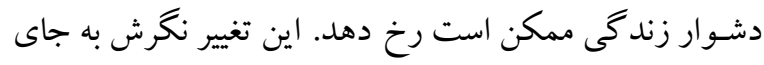

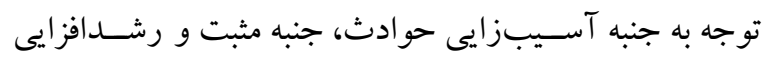
حوادث را مورد توجه قرار مىدهد. اين اصــطلاح كه توســط تديسجى و كالهون در سال 1999 ابداع شده است، به تغييرات روانشناختى مثبت اشاره دارد كه به وسيله مردم به عنوان نتيجه

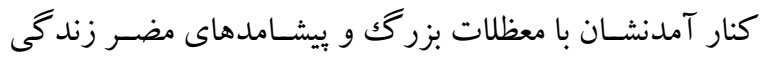

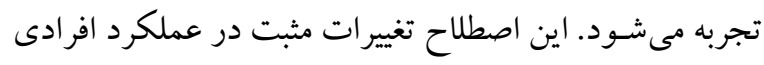
راكـه قبل از تروما موفق بودهاند، توصـيف مى كند و نشـــان

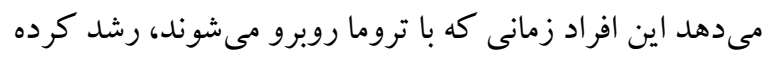

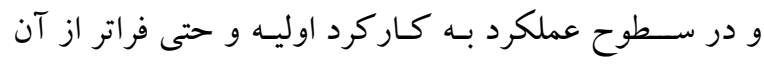

2. Post-Traumatic Growth (PTG)

\section{مقلممه}

اختلال نارسـايى توجه/ فزون كنشى نخستين بار در سال IAFD

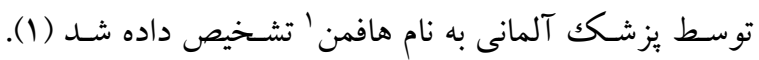

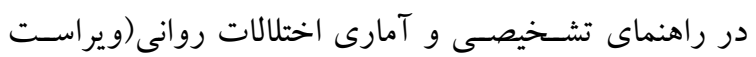
بنجم)، نارسايى توجه / فزون كنشى به معناى فقدان توجه و يا فزون كنشى - تكانش گرى بايدارى تعريف مى تشـود كه مانع

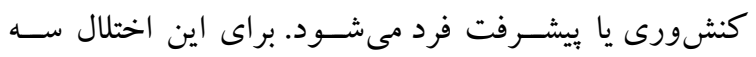

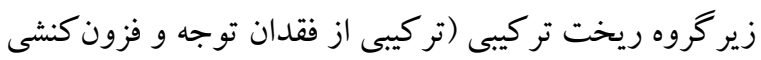

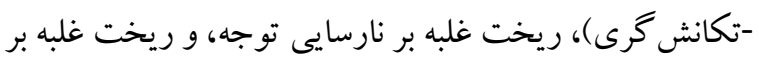
فزون كنشى - تكانشخرى تعريف شده است (Y). شروع اوليه نشانگان نارسايى توجه / فزون كنشى مربوط به ليه

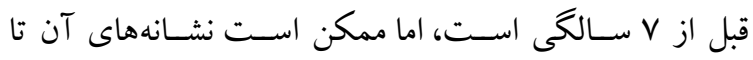

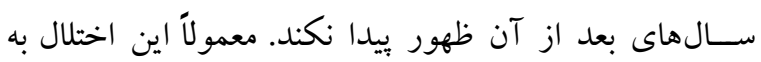

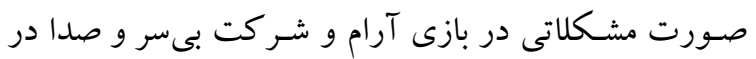
فعـاليـتهاى اوقات فراغت، جنبوجوش مفرط و برحرفى بروز مى يابد. ميزان شيوع نارسايى توجه/ فزون كنشى بر اساس

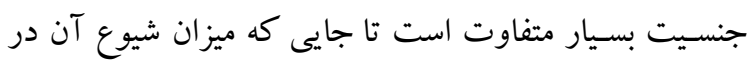

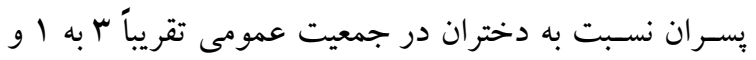

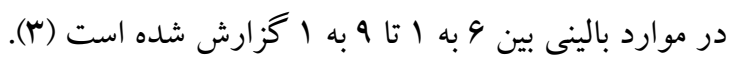
اثرات منفى اين اختلـال در كودكـان و نوجو انـان تنهـا بـــ حوزه اجتماعى و فردى منحصـــر نمى شـــود و مى توان به نظام

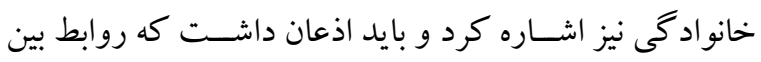

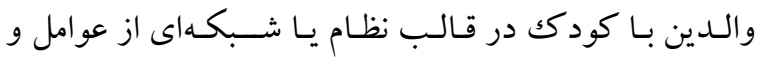
متغيرهـاى مختلف در هم تنيـده قابل بررسـى اســت. دوران

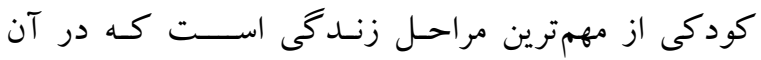

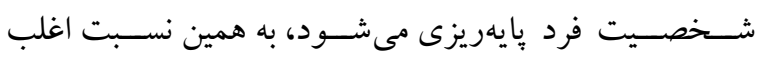

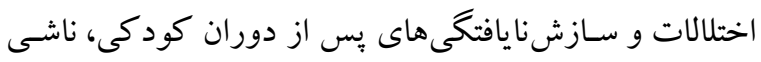

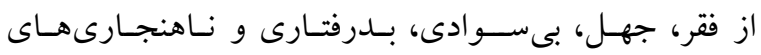

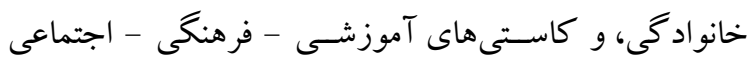
اسـت. در فرايند تحول كودك، محيط خانواده، مدرسـهـ، و و بالاخره اجتماع هر يكك داراى نقش مشـصى هستند، ولى از 
اين موضسوع اشـاره دارد كه تجارب و مشكلات زندگى فرد،

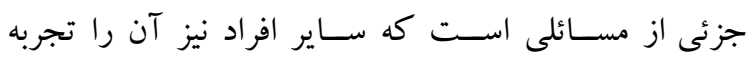
مى كنند. شـفقت به خود با احسـاس دوسـت داشـتن خود و نخرانى و مراقبت در مورد ديخران مرتبط اسـت، اما به معناى

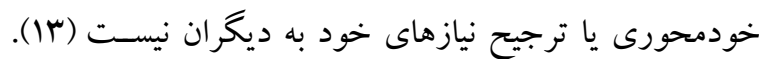

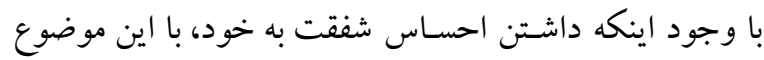

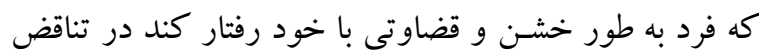

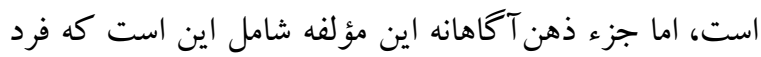

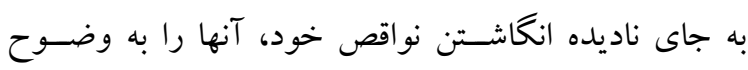

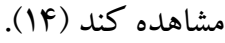
درمان متمر كز بر شفقت به اين موضسوع اشاره مى كند كه

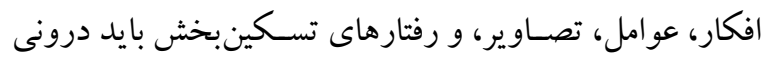

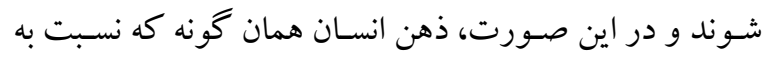
عوامل بيرونى واكنش نشان مىدهد، در مواجهه با درونيات نيز

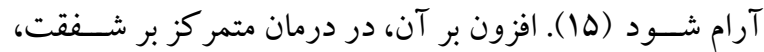
افر اد مى آموزند كه از احسـاسات دردناكك خود اجتناب نكرده و آنها را سر كوب نكنند؛ بنابر اين مى توانند در گام اول، تجربه خود را بشـناسـند و نسـبت به آن احسـاس شـفقت داشته باشند (19). در ايـن روش درمـانى بـه جـاى تـمركز بـر تـغيير

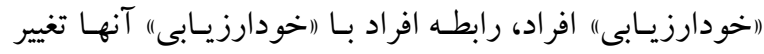
مسيـابـد. در تـمـريـنهـاى خودشــفتى بر تمرين آرامى،

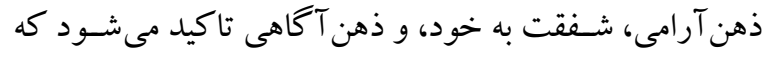

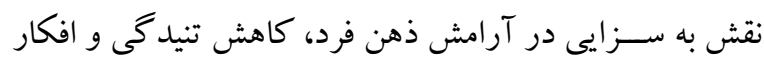

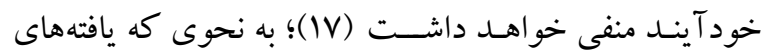
يُزوهشى متعلدى اثربخشسى اين روش درمانى بر سـازههاى

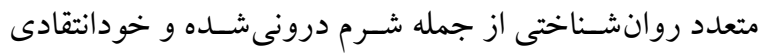

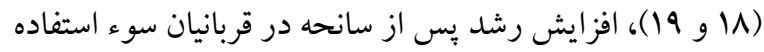

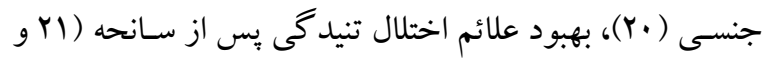

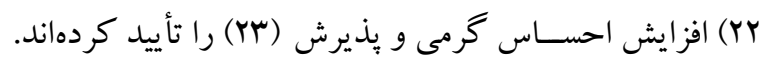
در هر صـورت تاكنون بِزوهشى كه بر رشـــ بِ از سانحه در

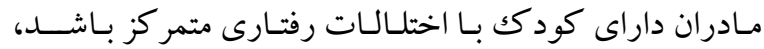
صورت نيذيرفته است، اين در حالى است كه نقش محيط اوليه

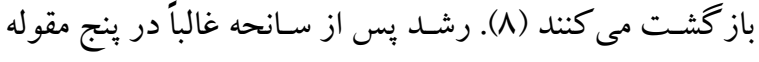

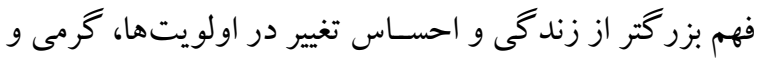

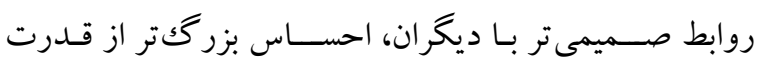
شـخصى، معنويت رشديافته، و توانايى هاى جديد تقسيمبندى روى شده است (9). (9)

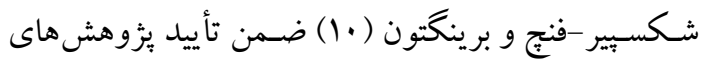

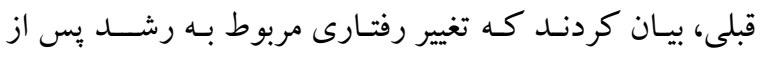
سـانحه، توسط تغييراتى در مسير شـلى، صرف زمان بيشتر با دوستان و خانواده و افزايش قدردانى دينى و مذهبى، مشخص مى شـود. وقتى افراد رشد يس از سانحه را تجربه مى كنند، آنها

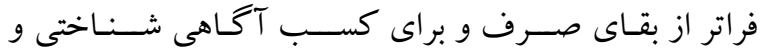

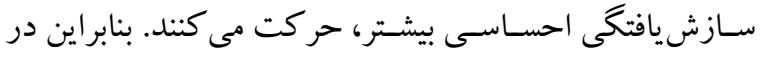

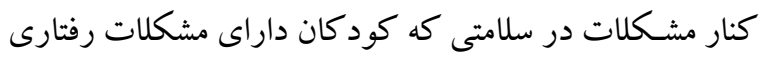
براى والـدين و بـه ويزه مادران ايجاد مى كنند، اما توجه به اين اصل اساسى مهم است كه بروز، شدت يافتن، و حتى تعديل و

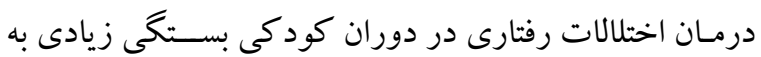

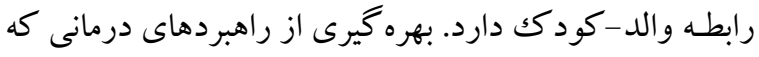
تقويت كننده ابعاد مثبت اين رابطه باشــ، از ضروريات درمانى تهره حال حاضر خو اهد بود. برهمين اساس يافته هاى بزوهشى متعدد

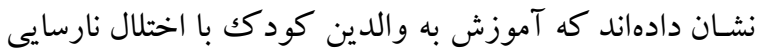
توجه / فزون كنشسى تأثير قابل توجهى بر تعامل والد - كودكى

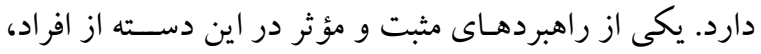
درمان مبتنى بر شفقت بر اساس اصول گيلبرت است.

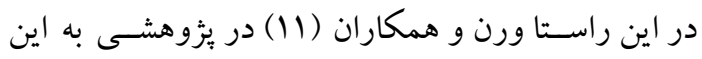
نتيجه رسـيدند كه بعد از كنترل متغيرهاى جمعيتشـناختى، شفقت به خود بيشبينى كننده مهمى براى عاطفه منفى، عاطفه

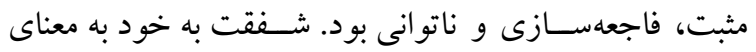

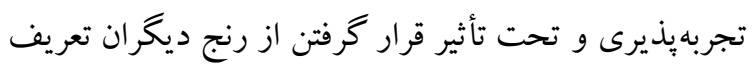

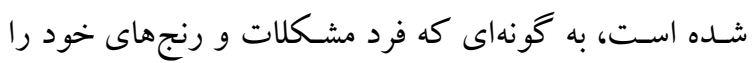
قابل تحملتر كند. همجنين اين مفهوم به معناى صسبور و

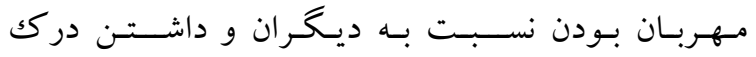
غيرقضـاوت گر انه در رابطه با آنهاسـت (Y) (I). علاوه بر اين، به 


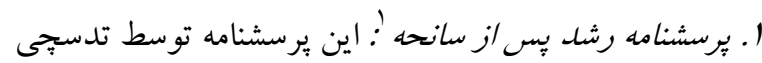
و كالهون در سـال 1999 به منظور بررسى مفهوم رشـــ يس از راز

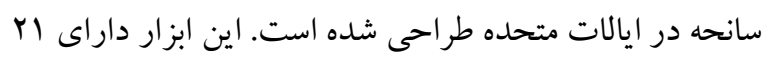

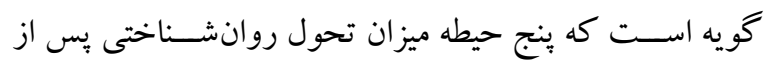

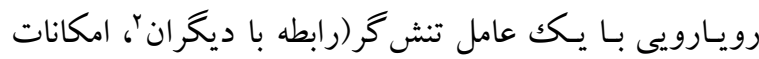

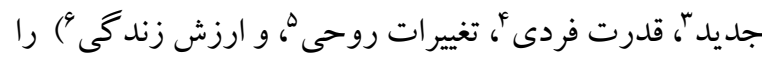

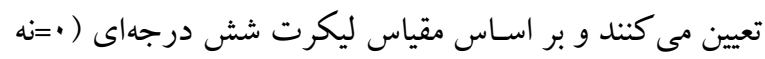

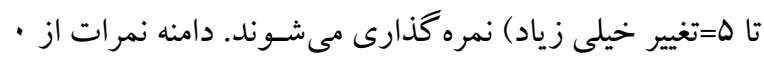

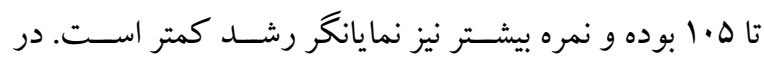

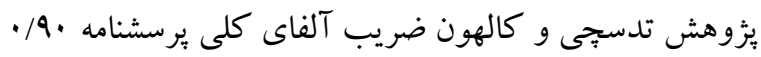
و دامنه آلفاى كرونباخ براى هر يكك از خرده مقياسها بين

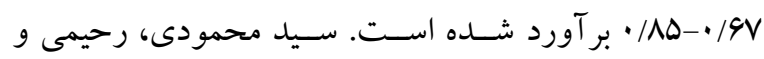

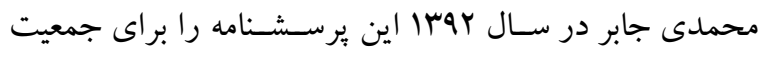
اير ان هنجاريابى كردند و گزارش كردند كه نسخه فارسى اين يرسـشـنامه شـامل f مؤلفه احسـاس قدرت درونى، تغيير در اهداف و اولويتها، احساس صميميت و نزديكى با ديخران، و و تلاش براى حفظ روابط با ديخران اسـت. آنان گزارش كردند

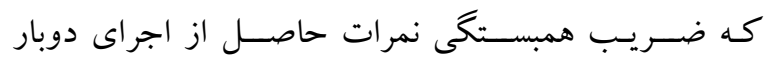
اندازه گيرى هq/· به دسـت آمد. ضــريب آلفاى كرونباخ

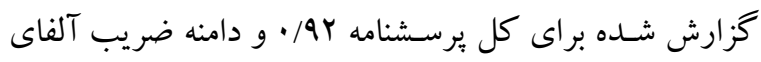

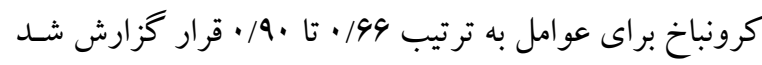

ج) برنـامــه مداخلهاى: كامهاى درمانى اين مطالعه مبتنى بر

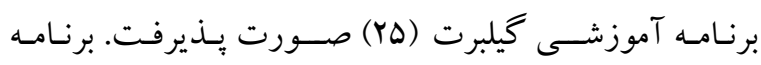
مداخلهاى طى ^ جلسه (هفتهاى ا جلسه، هر جلسه •9 دقيقه) با مشاركت مادران به آنها آموزش داده شد. برنامه مداخلهاى در

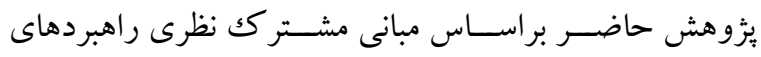
شـفقت به خود اسـت؛ بدين ترتيب كه هدف اصـلى از ارائه كامهاى درمانى - آموزشى، ايجاد توافق بين تهلديد و حفاظت

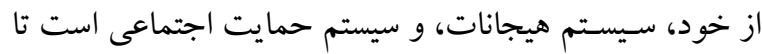

4. Individual power

5. Mental changes

6 . The value of life
و ارتباط مادر - فرزند در طى مسير تحول كودك در مراحل

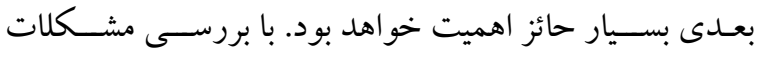

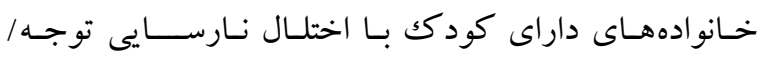
فزون كنشى و بررسى ابعاد سلامت روانشناختى مادران مىتوان

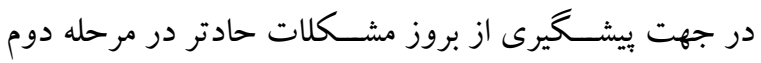
اقدام كرد، و از شدت يافتن مشكلات ناشى از اختلالات رفتارى

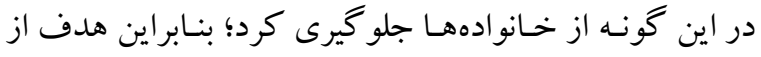

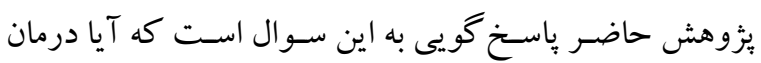

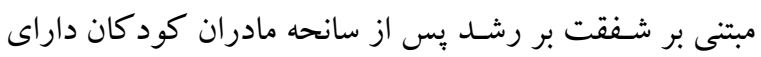

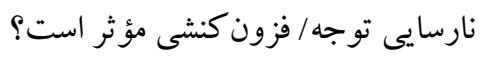

\section{روش} الف) طرح هئوهش و شـر كت كنند كان: يزوهش حاضـر از

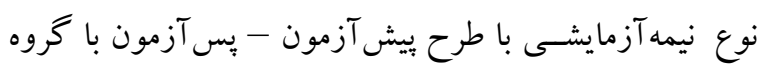

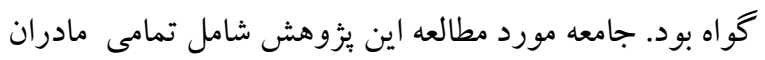
داراى كودك با اختلال نارسـايى توجه/فزون كنشـى شـهـ

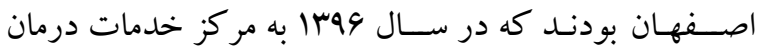
يزشـكى و روان يزشكى مراجعه كرده بودند. آزمودنىهاى اين

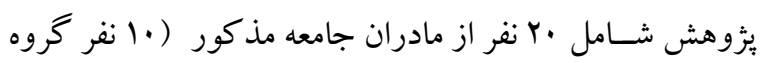

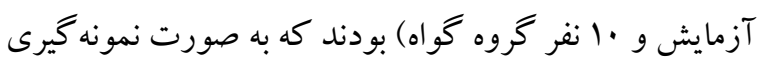
هدفمند از جامعه مذكور انتخاب شـــند. دامنهى ســى مادران

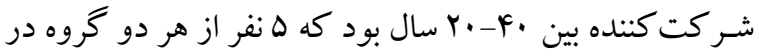

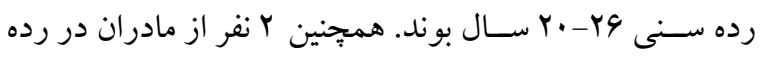

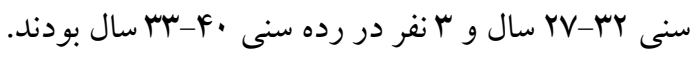
ملاككهاى ورود به ئزوهش حاضـر شـامل داوطلب بودن

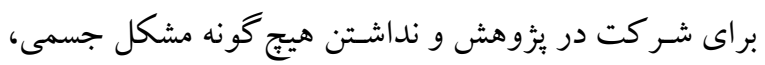

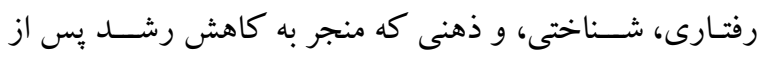
سانحه شود، و همجِنين ملاككهاى خروج شامل عدم همكارى كامل، غيبت بيش از دو جلسه، و عدم تكميل برسشنامه بود. ب) ابزار

1. Post-traumatic Growth Inventory (PTGA)

2. Relationship with others

3. New Features 
به كار گرفته شـل. برنامه مداخله توسط يكك كارشـناس ارشد روانشـناسى كه داراى گواهى گذراندن دوره شفقت درمانى بودند، اجرا شـده اسـت. جدول ا، خلاصهاى از محتواى جلسه درمانى را نشان مى دهد.
فرد از طريق ايجاد اين توافق و ياد گيرى مهارتهاى كليدى به

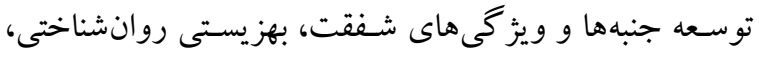

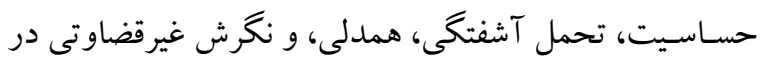

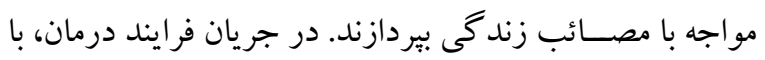
طرح برسش و ياسخ و بحث گروهى، تلاش و مشاركت مادران

جدول ا: محتواى جلسه درمانى

\begin{tabular}{|c|c|c|}
\hline محتوا & هدف & جلسه \\
\hline برقرارى ارتباط اوليه، مرورى بر ساختار جلسات، آشنايى با اصول كلى درمان مبتى بر شفقت، تمايز شفقت با تأسف & 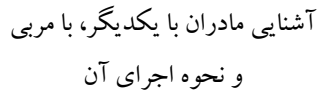 & اول \\
\hline 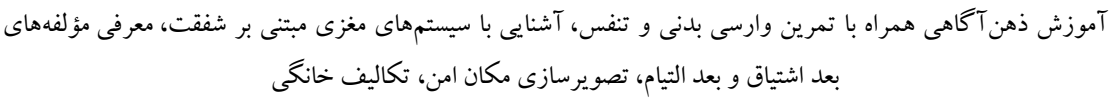 & آموزش ذهن آكاهى & دوم \\
\hline 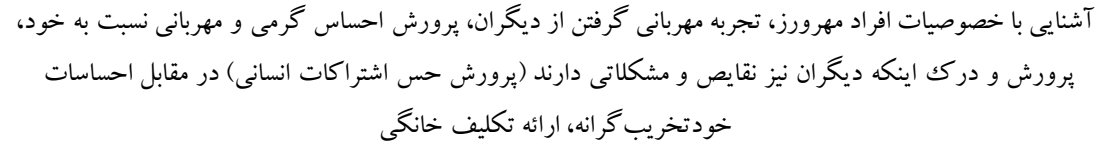 & بر بـى ويز كى افراد شفتتورز & سوم \\
\hline 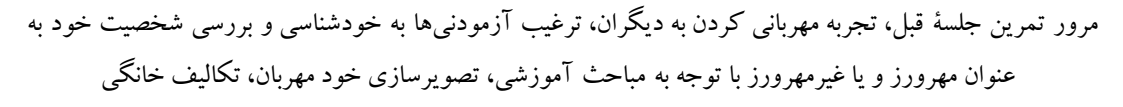 & خودشن & جهارم \\
\hline مرور تمرين جلسه قبل، تكميل فرم مصاحبه ذهن مهربان (بعد اشتياق)، تكاليف خانگى & تكميل فرم مطاحبه ذهن مهربان & هنجم \\
\hline مرور تمرين جلسه قبل، تكميل فرم مصاحبه ذهن مهربان (بعد التيام بخش)، تكاليف خانخى & 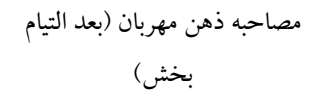 & ششم \\
\hline 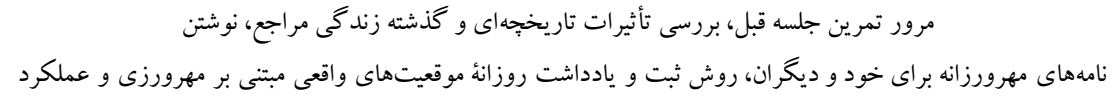 & نامه هاى مهرورزانه براى خود و & هفتم \\
\hline جمعبندى و ارائهُ راهكارهايى براى حفظ راهكارهاى مشفقانه، بكار گيرى اين روش درمانى در زندگى روزى رومره & 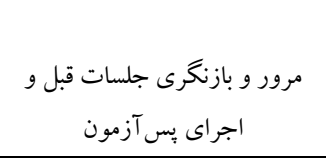 & هشتم \\
\hline
\end{tabular}

ذكر اســت در طول آموزش براى گروه آزمـايش، هيج گونه مداخلهاى روى گرووه گواه صورت نخرفت.

تمـامى ملـاحظـات اخلـاقى مـانــــمحر مـانه بودن اطلاعات شخصى، اجراى روش شفقتدرمانى براى مادران گروه گواه

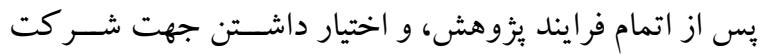
داشتن و خروج از يثوهش در اين مطالعه رعايت شد. دادهها با استفاده از نرمافزار rYSPS با آزمون تحليل كوواريانس تكك و جندمتغيره تحليل شد.
د) روش اجرا: ابتـدا مجوزهـاى للزم از دانشــاه و مديريت

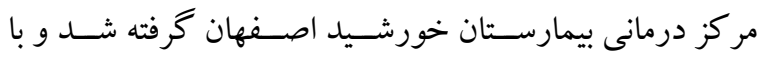
مـراجـعـه بـه مركز درمـانى، يس از بررســى يرونسـدهــاى روانشناختى كود كان مبتلا به اختلال نارسايى توجه/فزون كنشى و بر اســاس ملـاككهـاى ورود و خروج، دو گروه آزمايش و گ گواه تعريف شـدند. در نهايت مادران گروه آزمايش ^ جلسـه •q دقيقهاى و هفتهاى Y بار در كلاس ها شركت كردند. اجراى. برنامه شفقتدرمانى توسط يزوهشخر و در محل بيمارستان و به صورت گرووهى انجام شد. يّ از اجراى برنامه شفقتدرمانى براى گروه آزمايش در يايان جلسـات آموزشسى، هر دو گروه مجدداً يرســـنامه رشد يس از سانحه را تكميل كردند. للازم به 
براى بررسـى نرمـال بودن توزيع متغيرهـا در گروهها گزارش شـده است. با توجه به آماره Z اين آزمون براى تمامى متغيرها

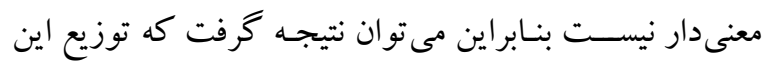

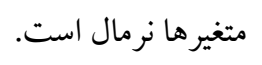

در جـدول r، اطلـاعات توصــيفى متغيرهاى بثرهش شــامل ميانخين و انحر اف استاندار و نمرات ييش آزمون - بِ بس آزمون

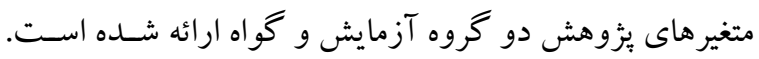

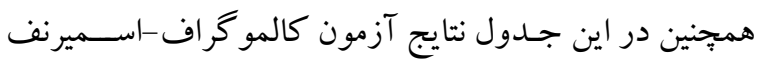

جدول ז: شاخصهاى توصيفى نمرات بيش آزمون و بس آزمون در دو كروه آزمايش و كواه

\begin{tabular}{|c|c|c|c|c|c|c|c|}
\hline \multicolumn{2}{|c|}{ كلموكراف - اسميرنف } & \multicolumn{2}{|c|}{ 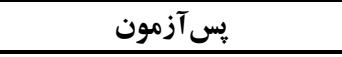 } & \multicolumn{2}{|c|}{ بيش آزمون } & \multirow[b]{2}{*}{ 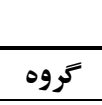 } & \multirow[b]{2}{*}{ متغيرها } \\
\hline $\mathbf{p}$ & K-S Z & انحراف استاندارد & ميانكين & انحر اف استاندارد & ميانكين & & \\
\hline \multirow{2}{*}{$\cdot / r$} & \multirow[b]{2}{*}{. } & $r / . r$ & $1 r / 4$ & $\Delta / \Delta r$ & 1. & 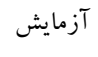 & \multirow[b]{2}{*}{ احساس قدرت درونى } \\
\hline & & $\Delta / r_{1}$ & $9 / \Delta$. & $\Delta / \Delta \Delta$ & $9 / r$ & كواه & \\
\hline \multirow{2}{*}{$\cdot 111$} & \multirow{2}{*}{ •/IY } & $\Delta / 19$ & $19 / 9$. & $1 / 19$ & $\mid F / r$ & 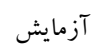 & \multirow{2}{*}{ تغيير در اهداف و اولويتها } \\
\hline & & $v / r v$ & if & $V / A V$ & $|r /|$ & 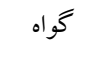 & \\
\hline \multirow{2}{*}{$\cdot / r$} & \multirow{2}{*}{$\cdot / 1 \%$} & r & if & $\Delta / \wedge F$ & $1 . / r r$ & 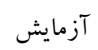 & \multirow[b]{2}{*}{ احساس نزديكى و صميميت با ديكران } \\
\hline & & $F / v 1$ & $9 / 4$ & $F / M k$ & $\Lambda / v$ & كواه & \\
\hline \multirow{2}{*}{$\cdot / r$} & \multirow{2}{*}{$\cdot / 10$} & $\Delta / v^{\prime}$ & $r \Delta / 1$. & $\Lambda / r \Delta$ & 19/9. & 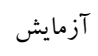 & \multirow{2}{*}{ تلاش براى حفظ روابط با ديكران } \\
\hline & & V/Ar & $|N|$ & V/AV & $\mid \mathrm{V} / \mathrm{r}$ & كواه & \\
\hline \multirow{2}{*}{.$/ 14$} & \multirow{2}{*}{.$/ 1 \mathrm{Y}$} & $1 N / 19$ & $9 N / 9$. & rV/aF & $\Delta r / \Delta \Delta$ & 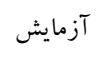 & \multirow{2}{*}{ رشد يس از سانحه } \\
\hline & & $r F / F F$ & $\Delta 1$ & $r k / F \mid$ & $F_{N / F}$ & 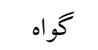 & \\
\hline
\end{tabular}

داد كه شيب رگرسيون در هر دو گروه برابر است (ه•/•>(p). نتايج آزمون خى دو بارتلت براى بررسى كرويت يا معنىدارى

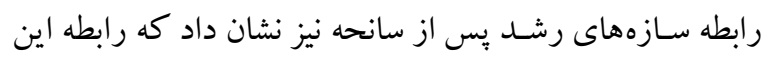

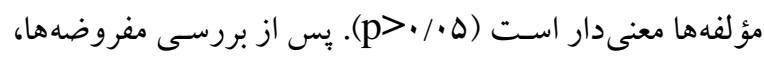
نتايج آزمون تحليل كوورايانس جندمتغيرى نشــان داد كه بين

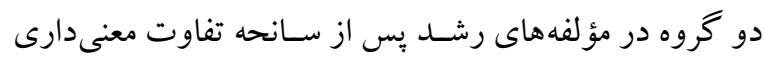
وجسود دارد (Wilk's براى بررسـى اين كه گروه آزمايش و گو اه در .Lambda=

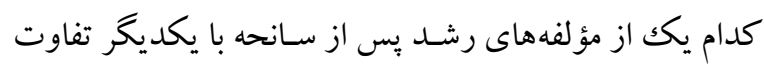

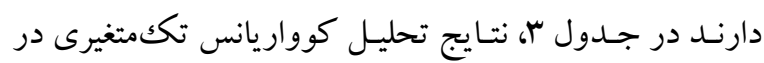
متن تحليل كووريانس جندمتغيرى گزارش شده است.
براى تعيين تاثر شـفقتدرمانى بر رشـــ بـ از سـانحه در

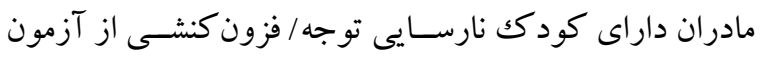
تحليل كوواريانس جندمتغيره استفاده شده است. نتايج آزمون لو ين براى بررسـى همكنى واريـانس متغيرهـاى وابسـتـهـ در

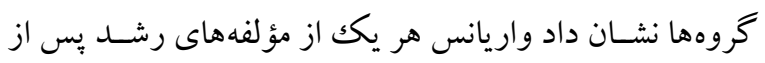

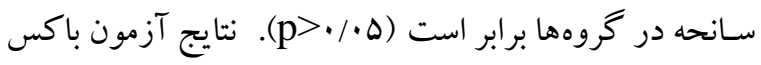
بر ایى بررسـى مـاتريس كوو اريانس متغيرهاى وابسـته در بين

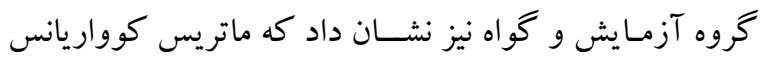

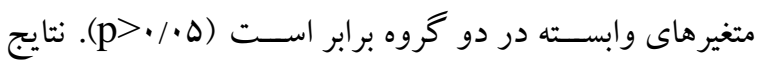

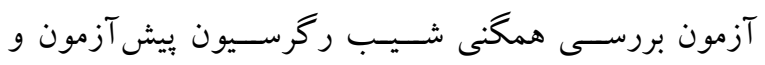

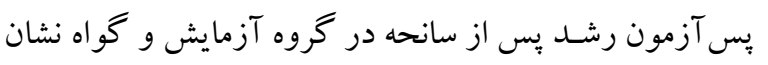

جدول "ّ: نتايج تحليل آنكوا در متن مانكوا براى بررسى مؤلفههاى رشد يّ از سانحه

\begin{tabular}{|c|c|c|c|c|c|c|}
\hline ضريب تأثير & $\mathbf{p}$ & Foار Fار & ميانكين مجذورات & درجه آزادى & مجموع مجذورات & شاخص مولفه ها \\
\hline$\cdot / \mu \wedge$ &.$/ \cdot 4$ & $1 / F V \Delta$ & GMF/GTV & 1 & $94 F / 94 V$ & احساس قدرت درونى \\
\hline$\cdot / \mu \Lambda$ & $\cdot / \cdot r$ & $r \cdot / r 9 \Lambda$ & $91 Y / \Delta$ Y & 1 & $91 Y / \Delta$ Y & تغيير در اهداف و اولويتها \\
\hline$\cdot / \Lambda$ & $\cdot / \cdot \Lambda$ & $r / r v q$ & $v \cdot / r \Delta r$ & 1 & $v \cdot / r \Delta r$ & احساس نزديكى و صميميت با ديخران \\
\hline$\cdot / \cdot r$ &.$/ 4 \pi$ & $.190 \mathrm{r}$ & $M Y / \cdot r q$ & 1 & $r Y / \cdot r q$ & تلاش براى حفظ روابط با ديخران \\
\hline
\end{tabular}


مختلف نشــان داد كـه روش شــقتـدرمانى منجر به كاهش

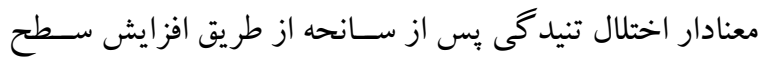
تعهد شـخصى، كاهش انزوا، و قضـاوت شـخصى شده است

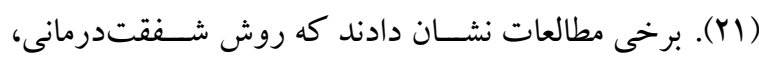

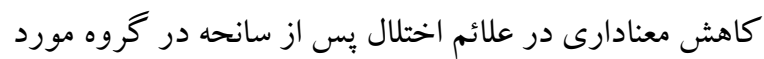

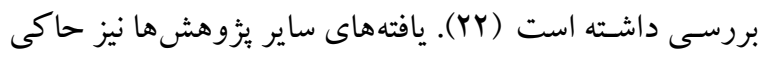
از آن اسـت كه شـفتـدرمانى از طريق كاهش شـرم ناشـى از تعارض و كاهش ابعاد خودانتقادى و خودسرزنش گرىى، منجر التر

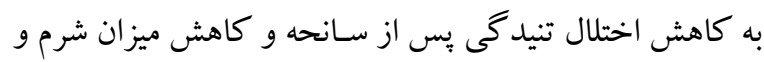
خودانتقادى در زنان شــده اسـت (1)). همجينين بوئيرسـما، هامانسـون، سـالومنسـون و جانسون (19) نيز نشان دادند كه در كروه نوجو انان داراى اختلال يّ از سانحه، ميزان شرم ناشى از رخــاد خـارج از مهـار فردى منجر بـهـ كـاهش علـائم اختلـال تنيدگى بس از سانحه شده است. در تبيين اين نتسايج مىتوان اذعـان كرد درمـان مبتنى بر سرة

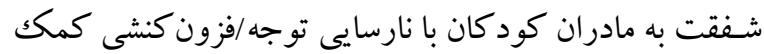

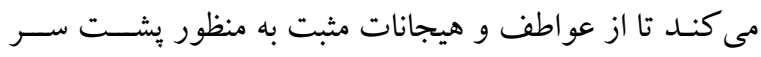

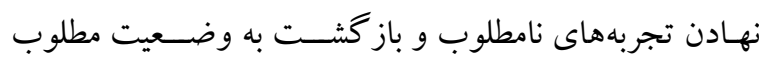
اسـتفاده كنند، به طورى كه در مواجهه با رويدادهاى هيجانى خنثى و نـامعلوم، بيشـتر تمايل به نشــان دادن هيجانات مثبت خو اهند داشت. درمان مبتنى بر شفقت با تسهيل تغيير هيجانات

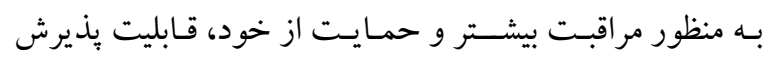
نار احتىها را بالا مىبرد و فرد را قادر مىسـازد تا خود را بيشتر

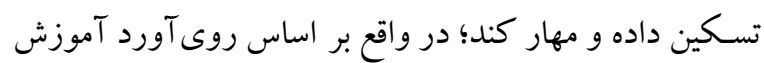

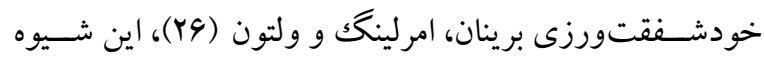
درمـان بـا آموزش خودنظمدهى هيجـانى، مهـار عو اطف، و و

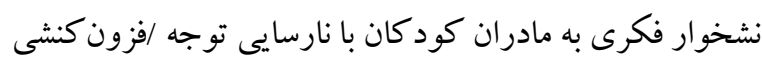

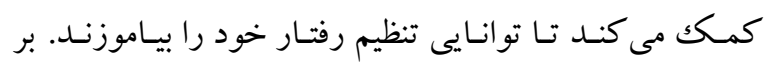

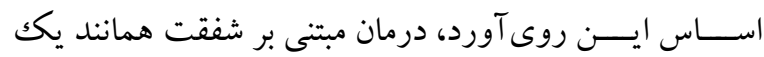
سـبك تنظيم هيجانى مثبت عمل مى كند و هيجانات منفى فرد را كاهش و هيجانات مثبت را جايكزين آن مى كند؛ بنابر اين به

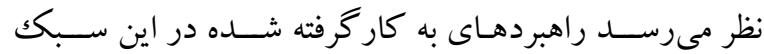

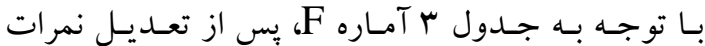
بيش آزمون، دو گروه گ گوه و آزمايش در متغير احساس قدرت

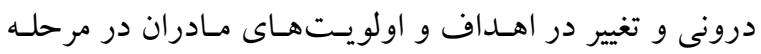

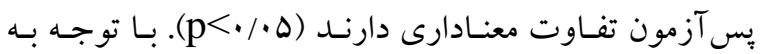
مجذور اتا، \&N/א درصــ از تفاوت در نمرات احســاس قدرت درونى و YN/A درصسـد از تفاوت در نمرات تغيير در اهداف و

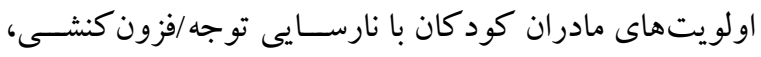
ناشسى از درمان مبتنى برشفقت بوده است. ضمن اينكه يُ إن از

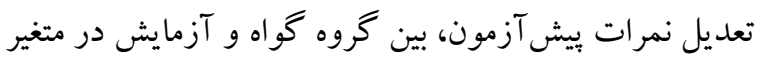

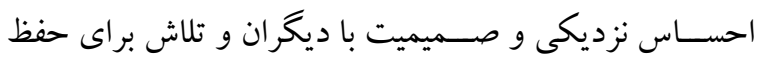

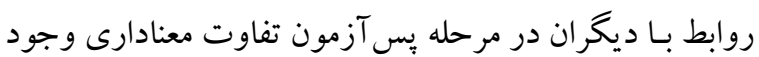

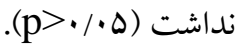

\section{بحث و نتيجل كيرى}

هدف بثزوهش حاضر بررسى اثر بخشى گرووهدرمانى مبتنى بر شـفقت بر رشـــ پِ از سـانحه مادران كود كان مبتلا به اختلال

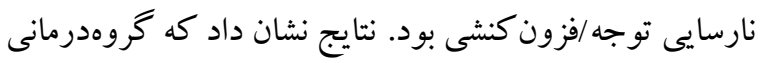
مبتنى بر شـفقـت بر متغير احســاس قدرت درونى، تغيير در اهداف، و اولويتهاى مادران مؤثر بوده است اما در سازههاى

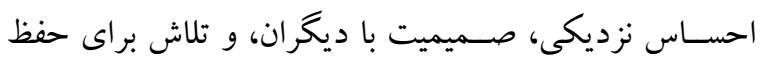

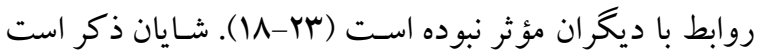

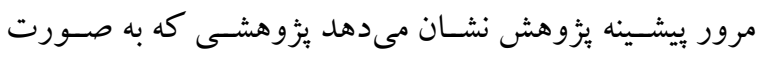

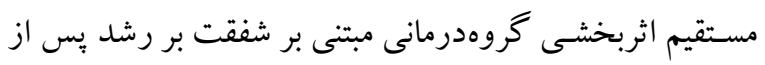

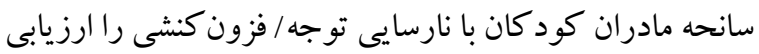

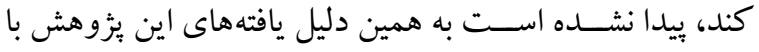

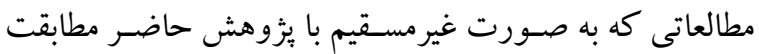
دارند، مقايسه شد. مطالعات مختلف نشان دادهاند روش درمان مبتنى بر شفقت بر بهبود سـازههاى رشـــ هـ از سـانحه در گروههايى مشـابه خانو ادههاى داراى كود كان با نارسايى توجه/فزون كنشى (مانند

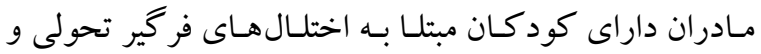

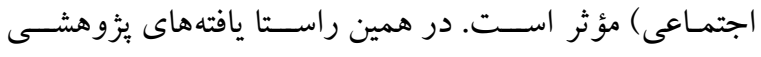


با شرايط خود را باز طراحى كرده و در نتيجه با تغيير اهداف و

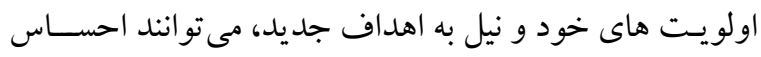
قدرت درونى بيشترى داشته باشند. در همين راستا فتحاللهزاده،

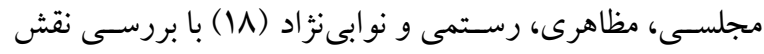
شـفــتـدرمـانى بر كـاهش شـــرم درونى و خودانتقادى زنان آزارديده عاطفى نشــان دادند كه راهبردهاى مبتنى بر شـفقت بـاعث مىشـــود كه اين افراد با برقرارى بيوند ميان خود تحت

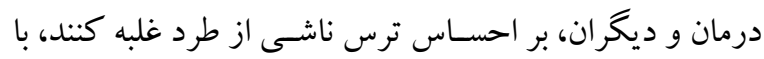

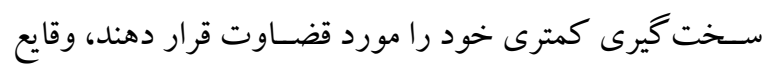
منفى مانند حضـور كودك دار ایى اختلال را راحت تر بيذيرند، و خودارزيـابىهـا و واكنشهـايشــان دقيقتر و بيشــتر بر وِايه عملكرد واقعى شـان باشـد. در نتيجه بر اسـاس اين شـيوه ميزان تسـلط درونى افراد، افزايش و ميزان خودانتقـادى منفى آنها

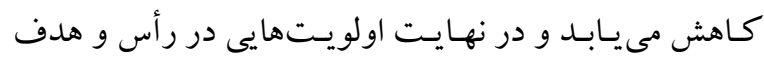
زندگى قرار مى گيرند كه ناشسى از قضـاوت منصـفانه نسبت به خود خواهد بود. نتيجه اين كه دور از ذهن نخواهد بود كه اين

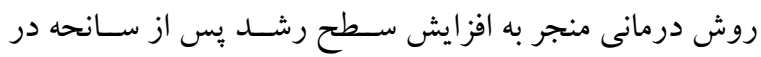

$$
\text { آزمودنىهاى گروه آزمايش شود. }
$$

يُزوهش حاضـر با محدوديتهايى نيز مواجه بوده اسـت.

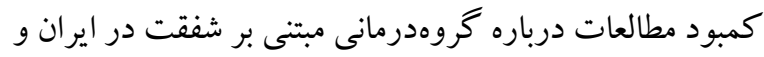
حتى خارج از كشـود در گروه مورد بررسـى، امكان بررسـى لايههاى بيشـتر و درونى تر اختلالات رفتارى كود كان در نظام

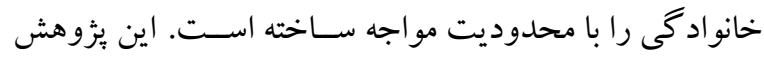
تـنهـا روى مـادران كودكــان مبتلـا بـهـ اختلـال نـارســـايى توجه/فزون كنشى انجام شد و امكان مطالعه روى يدران فراهم نشــد. از ســوى ديخر به دليل محدوديت زمانى و عدم امكان دسترسى طولانى مدت به مادران گرووه آزمايش و گو اه، امكان

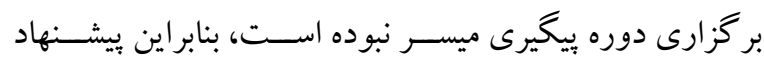

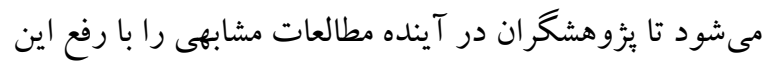
محـدوديـت هـا انجـام دهند تا دقت و تعميمدهى نتايج افزايش يابد. بر اسـاس يافتهاى يزوهش حاضـر بيشنهاد مىشود كه از

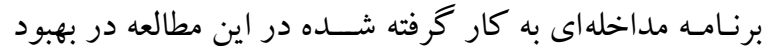

آموزشى مانند تمرين هاى مهرورزى (آرامسازى، ذهن آرام و

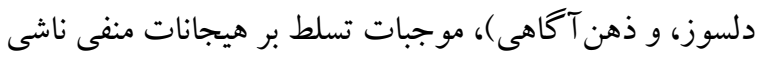

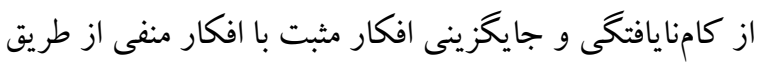

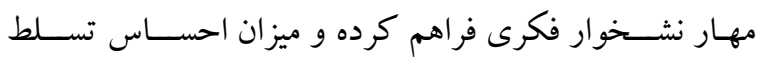
شخصى و درونى را افزايش مى دهد.

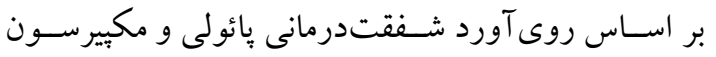

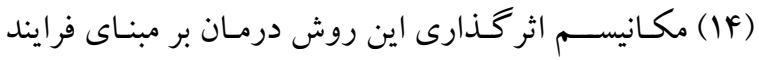
محورى است كه منجر به ارتقاء يذيرش تجربيات روانشناختى و تعهد با افزايش اعمال معنابخش، منعطف، سازش يافته، بدون در نظر گرفتن محتواى تجربيات روانشــاختى اسـت؛ بنابراين درك منعطف وقايع زندگى منجر به برداشـتى فر اسوى مفاهيم

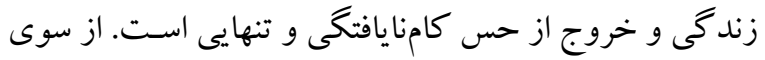

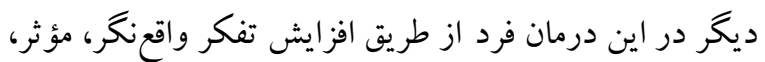
منطقى، و كـاهش اجتنـاب از تجربيـات روانشـــناختى به طور غيرمسـتقيم و افزايش آكاهى از وجود آنها با متمر كز كردن

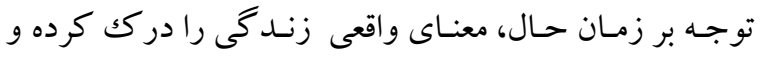

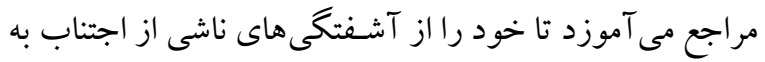

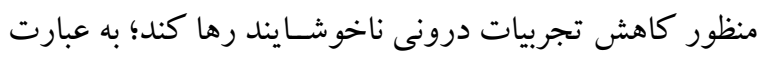
ديخر مى توان مكانيسـم اصسلى اثربخش بودن اين روش درمان

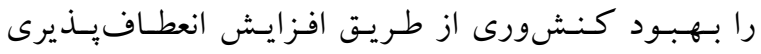
روانشناختى دانست، جه از اين طريق فرد مى تواند تا حدودى

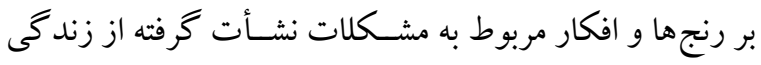

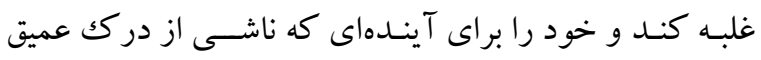

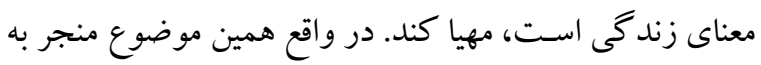

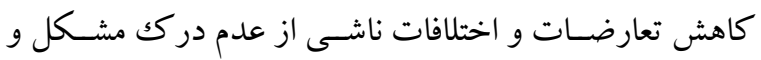
ريشهيابى جهت حل معظلات والدگرى خو اهد شد.

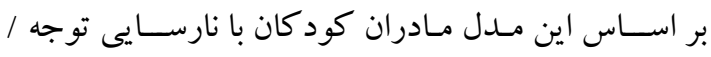

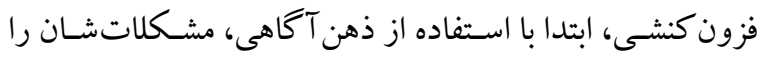

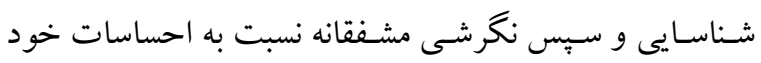
ويرامون مشكلات بيدا مى كنند و در نتيجه سطح بالاى انتظارات

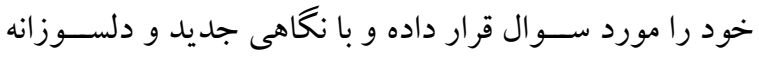
نسبت به خود، معيار هاى واقعى و توقعات قابل دستيابى متناسب 


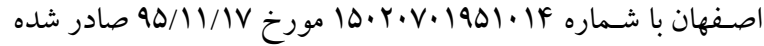

است. بلدين ترتيب از مديريت برسنل محترم بيمارستان خورشيد شهر اصـفهان كه ما را در انجام اين ئزوهش يارى رسـاندند و همجِنين از

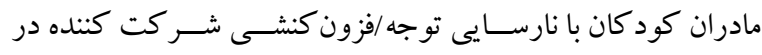
فرايند يُزوهش، تشكر و قدردانى مىشود.

تضاد منابع: اين بثوهش براى نويسندگان هيج گونه تضاد منافعى به دنبال نداشته است.
وضعيت روانى و كيفيت زندكى مادران داراى كود كك مبتلا به اختلال نارسايى توجه/فزون كنشى استفاده شود. تشكر و قدردانى: يُزوهش حاضسر بر گفته از باياننامه خانم مزّ گان

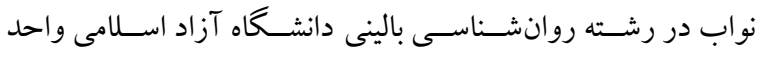
نجف آباد اصفهان با راهنمايى دكتر افسانه كرباسى و مشاورت دكتر اكرم دهقانى اسـت. همجينين مجوز اجراى آن بر روى افراد نمونه از سـوى واحد آموزش دانشـكاه آزاد اسـلامى واحد نجف آباد شـهـر 


\section{References}

1. Wu S-Y, Gau SS-F. Correlates for academic performance and school functioning among youths with and without persistent attention-deficit/hyperactivity disorder. Res Dev Disabil. 2013; 34(1): 505-515. [Link]

2. Bussing R, Porter P, Zima BT, Mason D, Garvan C, Reid R. Academic outcome trajectories of students with ADHD: Does exceptional education status matter? J Emot Behav Disord. 2012; 20(3): 131-143. [Link]

3. Gremillion ML, Martel MM. Semantic language as a mechanism explaining the association between ADHD symptoms and reading and mathematics underachievement. J Abnorm Child Psychol. 2012; 40(8): 1339-1349. [Link]

4. Tellegen CL, Sanders MR. Using primary care parenting interventions to improve outcomes in children with developmental disabilities: a case report. Case Rep Pediatr. 2012; 2012: 150261. [Link]

5. Mallers MH, Charles ST, Neupert SD, Almeida DM. Perceptions of childhood relationships with mother and father: daily emotional and stressor experiences in adulthood. Dev Psychol. 2010; 46(6): 16511661. [Link]

6. Taylor ZE, Larsen-Rife D, Conger RD, Widaman KF, Cutrona CE. Life stress, maternal optimism, and adolescent competence in single mother, African American families. J Fam Psychol. 2010; 24(4): 468477. [Link]

7. Whalen DJ, Sylvester CM, Luby JL. Depression and anxiety in preschoolers: a review of the past 7 years. Child Adolesc Psychiatr Clin N Am. 2017; 26(3): 503-522. [Link]

8. Tedeschi RG, Calhoun LG. " Posttraumatic growth: Conceptual foundations and empirical evidence". Psychol Inq. 2004; 15(1): 1-18. [Link]

9. Ramos C, Leal IP. Posttraumatic growth in the aftermath of trauma: A literature review about related factors and application contexts. Psychology, Community \& Health. 2013; 2(1): 43-54. [Link]

10. Shakespeare-Finch J, Barrington AJ. Behavioural changes add validity to the construct of posttraumatic growth. J Trauma Stress. 2012: 25(4): 433-439. [Link]

11. Wren AA, Somers TJ, Wright MA, Goetz MC, Leary MR, Fras AM, et al. Self-compassion in patients with persistent musculoskeletal pain: relationship of self-compassion to adjustment to persistent pain. J Pain Symptom Manage. 2012; 43(4): 759-770. [Link]

12. Neff KD. Self-compassion, self-esteem, and well-being. Soc Personal Psychol Compass. 2011; 5(1): 112. [Link]

13. Birnie K, Speca M, Carlson LE. Exploring self-compassion and empathy in the context of mindfulnessbased stress reduction (MBSR). Stress Health. 2010; 26(5): 359-371. [Link]

14. Pauley G, McPherson S. The experience and meaning of compassion and self-compassion for individuals with depression or anxiety. Psychol Psychother. 2010; 83(2): 129-143. [Link]

15. Gilbert P. The origins and nature of compassion focused therapy. Br J Clin Psychol. 2014; 53(1): 6-41. [Link]

16. Kelly AC, Wisniewski L, Martin-Wagar C, Hoffman E. Group-based compassion-focused therapy as an adjunct to outpatient treatment for eating disorders: a pilot randomized controlled trial. Clin Psychol Psychother. 2017; 24(2): 475-487. [Link]

17. Neff KD, Germer CK. A pilot study and randomized controlled trial of the mindful self-compassion program. J Clin Psychol. 2013; 69(1): 28-44. [Link]

18. Fatollahzadeh N, Majlesi Z, Mazaheri Z, Rostami M, Navabinejad S. The effectiveness of compassionfocused therapy with internalized shame and self- criticism on emotionally abused women. Psychological Studies. 2017; 13(2): 151-168. [Persian]. [Link]

19. Boersma K, Håkanson A, Salomonsson E, Johansson I. Compassion focused therapy to counteract shame, self-criticism and isolation. A replicated single case experimental study for individuals with social anxiety. J Contemp Psychother. 2015; 45(2): 89-98. [Link]

20. Ha N, Bae SM, Hyun MH. The effect of forgiveness writing therapy on post-traumatic growth in survivors of sexual abuse. Sex Relation Ther. 2019; 34(1): 10-22. [Link] 
21. Hoffart A, Øktedalen T, Langkaas TF. Self-compassion influences PTSD symptoms in the process of change in trauma-focused cognitive-behavioral therapies: a study of within-person processes. Front Psychol. 2015; 6: 1273. [Link]

22. Au TM, Sauer-Zavala S, King MW, Petrocchi N, Barlow DH, Litz BT. Compassion-based therapy for trauma-related shame and posttraumatic stress: Initial evaluation using a multiple baseline design. Behav Ther. 2017; 48(2): 207-221. [Link]

23. Shapira LB, Mongrain M. The benefits of self-compassion and optimism exercises for individuals vulnerable to depression. J Posit Psychol. 2010; 5(5): 377-389. [Link]

24. Seyed Mahmoodi SJ, Rahimi C, Mohammadi Jaber NA. Psychometric properties of posttraumatic growth inventory in an Iranian sample. Journal of Psychological Models and Methods. 2013; 3(12): 93108. [Link]

25. Gilbert P. Introducing compassion-focused therapy. Adv Psychiatr Treat. 2009; 15(3): 199-208. [Link]

26. Brennan MA, Emmerling ME, Whelton WJ. Emotion-focused group therapy: Addressing self-criticism in the treatment of eating disorders. Couns Psychother Res. 2015; 15(1): 67-75. [Link] 